\title{
血清蛋白質の分画別抽出法による正常値
}

（文部省科学試験研究費による研究）

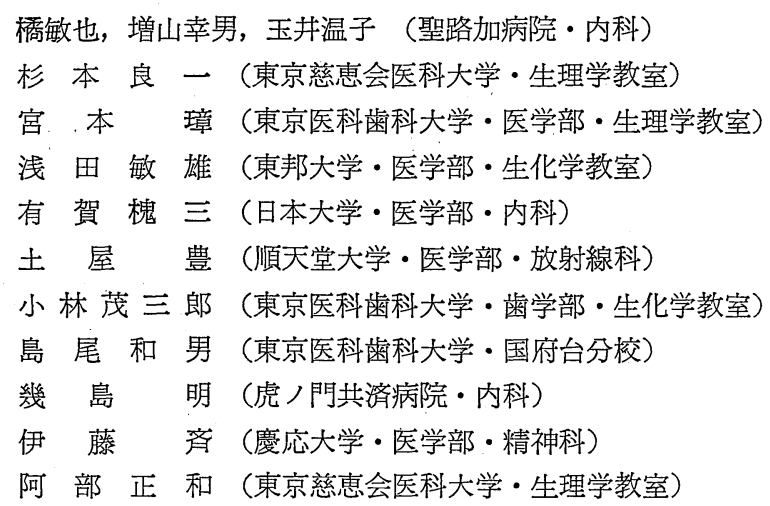

\section{Normal Value of Serum Protein Fractions by Fractionating Elution Method}

\author{
Toshiya Tatibana \\ Clinic of Internal Medicine, St. Lukes International \\ Hospital. \\ Ryoiti Sugimoto \\ Department of Physiologie, Jikei-kai University \\ school of Medicine. \\ Akira Miyamoto \\ Department of Physiology, Tokyo Medical and Dental \\ University. \\ Toshio Asada \\ Department of Biochemistry, Toho University School \\ of Medicine. \\ Kaizo Ariga \\ Department of Internal Medicine, Nihon University \\ School of Medicine. \\ Yutaka Tsutiya Department of Radiology, Juntendo University School \\ of Medicine. \\ Mosaburō Kobayashi \\ Department of Biochemistry, Tokyo Medical and \\ Dental University. \\ Kazuo Shimao \\ Faculty of Pre-medical and Pre-dental courses, \\ Tokyo Medical and Dental University. \\ Akira Ikushima \\ Clinic of Internal Medicine, Toranomon Hospital. \\ Akira Ito \\ Department of Pschyatry, Keio-Gijuku University \\ School of Medicine. \\ Masakazu Abe \\ Department of Physiologie, Tokyo Jikei-kai University \\ School of Medicine.
}




\section{血清蛋白質の分画別抽出法による正常値}

\section{Normal Value of Serum Protein Fractions by Fractionating Elution Method}

濾紙電気泳動法によつて分析された血清蛋白分画の濃 度比の再現性を,できる限り良好ならしめる操作法の案 出を目的として, 昭和 32 年電気泳動学会内に滤紙電気 泳動標準操作法小委員会が設置され, その試案が第 8 回 電気泳動学会総会に括いて発表された1)。このさいこの 試案に則つて東京都内の 14 力所の研究施設が同じ血清 試料を用いて泳動し，実験結果を比較検討したところ， albumin $+\alpha_{1}$-globulin の濃度比 (\%) の変動範囲 (最大 $9 \%$ 一最小 $9 \%$ ) が $20 \%$ 以上も崖つた。そこでさらに この問題の本質を衝くべく, 文部省の昭和 33 年度科学 試験研究費の援助を得て新しく研究班が結成された。こ の研究の目的は, 前述の大きなバラツキの原因を明らか にし, 初期の目標である良好な再現性をるつ標準操作法 を確立することであつた。

濾紙電気泳動法による血清蛋白質の大きなバラツキの 原因については, 既に昭和 32 年の標準操作法小委員会 の協同実験による研究によつて, densitometry にある ことが明らかとされていたが, 文部省の科学試験研究費 による研究班の追試検討は, この点を更に明らかにし, 濾紙電気泳動法による血清蛋白分画の濃度比に大きなバ ラッキを生ずる原因の 1 つは，実に densitometer および densitometry のテクニックにあることを明らか にした。これらの事実から, densitometer の性能の統 一, densitometry のテクニックの撖密な標準化の必要 性が強調されるに至つた。

以上の如く, 濾紙電気泳動法に上る血清蛋白分画の再 現性の低さの原因が， densitometryにあることに鑑み， これに代るものとして滳ら ${ }^{233)}$ は densitometry を用い
ない分画別抽出法 (fractionating elution method)を 試みていたが, 昭和 33 年度の試験研究費によつて, こ の分画別抽出法をとり上げて検討を行うこととした。そ してこの研究班の分画別抽出法に関する結論は次のよう なものであつだ”。すなわち, 分画別抽出法は densitometry に比較してきわめて再現性が良好であるとい らことであつた。しかし，この結果は実験者数の少なか つたことから決定的なことはいえないが，将来その実施 法の簡単な点を考慮すれば利用価值が大なる可能性のあ ることも考えられ，抽出操作の基礎的資料を早急集積 することと, 分画別抽出法による血清蛋白分画の正常值 を提出することの必要性が考兄られた。たまたま, 昭和 34 年度の文部省科学試験研究費の援助が得られることに なつたので, 分画別抽出法に関する研究を更に進展する ことになつたものである。この度の研究では, 分画別抽 出法に上る血清蛋白分画の正常值を得ること, 执よび 2,3 の疾患についての血清蛋白分画值を densitometry 法と分画別抽出法とで比較を行うことに重点が特かれた のである。

\section{実験方法}

濾紙電気泳動, 乾燥, BPB染色, 脱色はすでに発表さ

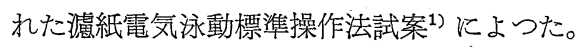

分画別抽出法沶よび比色法は, 虂らの方法 ${ }^{5}$ 飞準拠乙 た。

\section{実験成績並に考察}

1. 分画別抽分法と densitometry との比較

第 1 表 正常血清蛋白分画值

\begin{tabular}{|c|c|c|c|c|c|c|c|c|c|c|c|}
\hline \multirow{3}{*}{ 番 } & \multirow{3}{*}{ 号 } & \multirow{3}{*}{ alb. $\%$} & \multicolumn{4}{|c|}{ 分画別抽出 法 } & \multicolumn{5}{|c|}{ densitometry } \\
\hline & & & \multicolumn{4}{|c|}{ glob. $\%$} & \multirow{2}{*}{ alb. $\%$} & \multicolumn{4}{|c|}{ glob. $\%$} \\
\hline & & & $\alpha_{1}$ & $\alpha_{2}$ & $\beta$ & $r$ & & $\alpha_{1}$ & $\alpha_{2}$ & $\beta$ & $r$ \\
\hline & 1 & 71.5 & 3.3 & 5.3 & 6.6 & 13.3 & 58.4 & 4.6 & 6.5 & 9.2 & 21.3 \\
\hline & 2 & 69.0 & 1.4 & 5.2 & 8.9 & 15.5 & 60.0 & 3.5 & 4.3 & 10.4 & 21.8 \\
\hline & 3 & 68.6 & 4.5 & 5.8 & 8.5 & 12.6 & 65.9 & 2.0 & 6.1 & 7.1 & 19.2 \\
\hline & 4 & 62.8 & 4.8 & 5.4 & 9.3 & 17.7 & 52.8 & 5.3 & 8.1 & 10.2 & 23.6 \\
\hline & 5 & 61.8 & 7.0 & 6.0 & 9.2 & 11.0 & 55.5 & 4.2 & 7.1 & 18.2 & 15.5 \\
\hline & 6 & 61.7 & 5.7 & 6.4 & 9.4 & 16.8 & 56.9 & 6.1 & 7.5 & 10.3 & 19.2 \\
\hline & 7 & 61.2 & 4.5 & 6.6 & 9.3 & 18.4 & 51.5 & 4.0 & 7.6 & 11.6 & 25.2 \\
\hline & 8 & \multicolumn{2}{|c|}{70.4} & 5.5 . & 7.6 & 14.5 & \multicolumn{2}{|c|}{70.5} & 5.5 & 8.4 & 15.6 \\
\hline
\end{tabular}


第 2 表 .ネフローゼ血清蛋白分画值

\begin{tabular}{|c|c|c|c|c|c|c|c|c|c|c|c|}
\hline \multirow{3}{*}{ 番 } & \multirow{3}{*}{ 号 } & \multicolumn{5}{|c|}{ 分画 別 抽 出法 } & \multicolumn{5}{|c|}{ densitometry } \\
\hline & & \multirow{2}{*}{ alb. $\%$} & \multicolumn{4}{|c|}{ glob. $\%$} & \multirow{2}{*}{ alb. $\%$} & \multicolumn{4}{|c|}{ glob. $\%$} \\
\hline & & & {$\left[\alpha_{1}\right.$} & $\alpha_{2}$ & $\beta$ & $r$ & & $\alpha_{1}$ & $\alpha_{2}$ & $\beta$ & $\gamma$ \\
\hline & 1 & 17.8 & 4.2 & 36.7 & 26.3 & 15.0 & 22.4 & 4. 2 & 33.0 & 25.5 & 14.9 \\
\hline & 2 & 27.7 & 6.2 & 26.5 & 20.9 & 18.7 & 29.0 & 5.8 & 23.3 & 25.6 & 16.3 \\
\hline & 3 & 39.5 & 6.2 & 18.1 & 15.5 & 20.7 & 36.7 & 5.3 & 19.5 & 13.6 & 24.9 \\
\hline & 4 & 41.0 & 5.7 & 16.0 & 15.7 & 21.6 & 36.2 & 5.1 & 22.2 & 14.8 & 21.7 \\
\hline & 5 & \multicolumn{2}{|c|}{45.7} & 18.1 & 15.5 & 20.7 & \multicolumn{2}{|c|}{42.0} & 19.5 & 13.6 & 24.9 \\
\hline
\end{tabular}

第 3 表 肝硬変血清蛋白分画值

\begin{tabular}{|c|c|c|c|c|c|c|c|c|c|c|c|}
\hline \multirow{3}{*}{ 番 } & \multirow{3}{*}{ 号. } & \multicolumn{5}{|c|}{ 分画別抽. 出法 } & \multicolumn{5}{|c|}{ densitometry } \\
\hline & & \multirow{2}{*}{ alb. $\%$} & \multicolumn{4}{|c|}{ glob. $\%$} & \multirow{2}{*}{ alb. $\%$} & \multicolumn{4}{|c|}{ alb. $\%$} \\
\hline & & & $\alpha_{1}$ & $\alpha_{2}$ & $\beta$ & $r$ & & $\alpha_{1}$ & $\alpha_{2}$ & $\beta$ & $\gamma$ \\
\hline & 1 & 48.1 & 3.1 & 4.5 & 9.4 & 35.0 & 38.8 & 4.4 & 5.5 & 11.1 & 40.2 \\
\hline & 2 & 48.2 & 3.3 & 4.7 & 9.2 & 34.6 & 39.2 & 4.0 & 5.8 & 9.2 & 41.8 \\
\hline & 3 & 51.7 & 3.5 & 3.9 & 7.7 & 33.3 & 44.1 & 3.2 & 4.8 & 9.0 & 35.9 \\
\hline & 4 & \multicolumn{2}{|c|}{51.1} & 4.5 & 9.4 & 35.0 & \multicolumn{2}{|c|}{43.3} & 5.3 & 11.1 & 40.3 \\
\hline
\end{tabular}

\section{1）正常血清}

8 例の正案血清を資料として分画值を上げると第 1 表 の如くである。

これをとくに albumin 特よび $\boldsymbol{\gamma}$-globulin について 整理してみると, 次のようになる。

すなわち， albuminについて全例に和いて分画別抽出 法による方が高值を示し, 両方法による差は最大 13.1 $\%$, 最小 $2.7 \%$, 平均 $8.0 \%$ となつた。また, $r$-globulin については全例に执いて densitometry 法による值が高 值を示し，その差は最大 $8.0 \%$, 最小 $1.1 \%$, 平均 5.2 \%であつた。

\section{2）ネフローゼ血清}

5 例のネフローゼ血清について分画別抽出法と densitometer による分画值を上げたのが第 2 表である。

これをさらに albumin 特よび- $\alpha_{2}$-globulin の両分画 について整理してみると次のようになる。すなわち， albumin については, 分画別抽出法の方が高值を示する の 3 例, densitometry の方が高值を示するの 2 例であ つた。 $\alpha_{2}$-globulinについてる, 分画別抽出法の方が高值 を示するの 2 例, densitometry の方が高值を示すもの 3 例であつた。

3）旰硬変血清

肝硬変血清 4 例についての血清蛋白分画值を上げたの が第 3 表である。

これをさらに albumin 抌よび $r$-globulin の両分画に
ついて整理してみると次のよ5になる。

すなわら，albuminについては分画別抽出法が常に高 く,その差は平均 $8.6 \%$ であつた。また， $r$-globulin に ついては逆に densitometry の方が常に高值を示し, そ の差は平均 $5.1 \%$ であつた。

以上分画別抽出法と densitometry による血清蛋白分 画値の比較を，正常血清 8 例，ネフローゼ血清 5 例，肝 硬変血清 4 例について行つたが，正常血清ではalbumin は常に抽出法が高く，r-globulin は常に densitometry 法が高い。ネフローゼ血清については, そのalbuminの 低いものほど抽出法による值が低い傾向を示している。 ネフローゼ血清の $\alpha_{2}$-globulin についても, はつきり した傾向がみられていない。さらに肝硬変血清では albumin は常に抽出法が， $r$-globulin は常に densitometry によ一る值が高い。

一般に抽出法は densitometry 法に比べ albumin が 高く, $r$-globulin の低くでる傾向を示すが，ネフローゼ のように albumin がいちじるしく低下する疾患では， densitometry 法との差が小さくなり，albumin が極度 に低くなると，遂には逆転して densitometry によつて 得られる值の方が高く出る。 $\gamma$-globulin についてもこの 傾向がみとめられ，r-globulin の高く出る疾患，たとえ ば肝硬変の血清では densitometry による值の方が抽出 法よりも高く出る傾向が示された。

このように分画別抽出法と densitometryによる分画 
第 4 表 分画別抽出法による年代別血清蛋白分画の正常值

\begin{tabular}{|c|c|c|c|c|c|c|c|}
\hline \multirow{2}{*}{ 年 代 } & \multirow{2}{*}{ 例 数 } & \multirow{2}{*}{ alb. } & \multicolumn{4}{|c|}{ glob. } & \multirow{2}{*}{ 血清蛋白濃度 } \\
\hline & & & $\alpha_{1}$ & $\alpha_{2}$ & $\beta$ & $r$ & \\
\hline $18 \sim 19$ & $62^{\text {人 }}$ & $\begin{array}{r}\% \\
58.7 \pm 2.9\end{array}$ & $\begin{array}{r}\% \\
6.3 \pm 1.0\end{array}$ & $\begin{array}{r}\% \\
8.4 \pm 1.3\end{array}$ & $\begin{array}{r}\% \\
10.4 \pm 0.9\end{array}$ & $16.2 \pm 1.1$ & $\begin{array}{r}\mathrm{g} / \mathrm{dl} \\
7.6 \pm 0.5\end{array}$ \\
\hline $20 \sim 29$ & 18 & $62.8 \pm 3.9$ & $5.4 \pm 1.1$ & $7.0 \pm 1.3$ & $8.6 \pm 1.3$ & $16.2 \pm 2.4$ & $7.5 \pm 0.3$ \\
\hline $30 \sim 39$ & 7 & $65.9 \pm 3.9$ & $4.5 \pm 0.7$ & $5.7 \pm 0.7$ & $8.4 \pm 1.3$ & $15.5 \pm 2.3$ & $7.7 \pm 0.3$ \\
\hline $40 \sim 49$ & 27 & $64.3 \pm 3.6$ & $5.3 \pm 0.7$ & $6.7 \pm 1.0$ & $8.9 \pm 1.0$ & $14.8 \pm 2.6$ & $7.3 \pm 0.5$ \\
\hline $50 \sim 59$ & 12 & $62.6 \pm 4.6$ & $5.9 \pm 1.4$ & $7.0 \pm 1.0$ & $8.3 \pm 1.0$ & $16.2 \pm 3.4$ & $7.3 \pm 0.4$ \\
\hline $60 \sim 69$ & 4 & $62.3 \pm 1.4$ & $6.3 \pm 1.5$ & $6.8 \pm 0.9$ & $9.2 \pm 0.7$ & $15.4 \pm 0.7$ & $7.2 \pm 0.2$ \\
\hline 平 均 & 130 & $62.8 \pm 1.2$ & $5.6 \pm 0.6$ & $6.9 \pm 0.7$ & $9.0 \pm 0.8$ & $15.7 \pm 0.5$ & $7.4 \pm 0.2$ \\
\hline
\end{tabular}

第 5 表 分画別抽出法による血清蛋白分画值の性別

\begin{tabular}{|c|c|c|c|c|c|c|c|}
\hline \multirow{2}{*}{ 性 別 } & \multirow{2}{*}{ 例 } & \multirow{2}{*}{ alb. } & \multicolumn{4}{|c|}{ glob. } & \multirow{2}{*}{ 血清蛋白濃度 } \\
\hline & & & $\alpha_{1}$ & $\alpha_{2}$ & $\beta$ & $r$ & \\
\hline 男 & $8^{\text {人 }}$ & $\begin{array}{r}\% \\
64.9 \pm 5.0\end{array}$ & $\begin{array}{r}\% \\
4.7 \pm 1.1\end{array}$ & $\begin{array}{r}\% \\
6.3 \pm 0.7\end{array}$ & $8.3 \pm 1.3$ & $\begin{array}{r}\% \\
15.8 \pm 3.3\end{array}$ & $\begin{array}{r}\text { g/d } \\
7.4 \pm 0.2\end{array}$ \\
\hline 女 & 10 & $61.1 \pm 5.3$ & $6.0 \pm 2.8$ & $7.5 \pm 0.6$ & $8.9 \pm 1.4$ & $16.5 \pm 1.8$ & $7.6 \pm 0.5$ \\
\hline
\end{tabular}

值の差は常に一定とは限らないので, どちらかの成績, たと党ば densitometryによる分画值から抽出法による 值を推定することは不可能のようである。この事実は, 成績の評価に当つては常に同一の方法で得られたものに ついて比較しなければ意味のないことを示している。徒 つて将来分画別抽出法による各種疾患についての成績を もとめて発表して扣くことが必要であろう。

\section{2. 分画別抽出法による正常值}

$\mathrm{S}$ 女子短大入学試験応募者の うち, 病歷, 一般身体検 査, 一般検尿, 一般血球計算, 血沈, 梅毒血清反応, 胸 部レントゲン検査のすべてに合格した 18〜19 才の女子 学生 62 人, 抒よび $\mathrm{S}$ 病院勤務の医師, 看護婦, 検査室 技術士の正常者とみなされる者，人間ドックに和いて正 常者とみとめた人達 68 人, 計 130 人について, その血 清蛋白を濾紙電気泳動法によつて分析し, 分画別抽出法 に基づいて血清蛋白分画值を求めてみた。その成績は第 4 表に示すと㧤りである。

年代による有意の差はみとめられない。130人の平均 值は albumin $62.8 \pm 1.2 \% ， \alpha_{1}$-globulin $5.6 \pm 0.67$, $\alpha_{2}$-globulin $6.9 \pm 0.7 \%, \quad \beta$-globulin $9.0 \pm 0.8 \%, \quad \gamma$ globulin $15.7 \pm 0.5 \%$ であつた。

さらに 20２9 才代の被検者について性別を検討して みると第 5 表に示すと打りとなつた。この表にみられる ように男女間にはとくに有意の差がみとめられない。
1）正常血清, ネフローゼ血清, 硬変血清について濾 紙電気泳動分析を実施し, 分画別抽出法々 densitometry によつて得られる血清蛋白分画值を比較検討した。

2）正常血清についてみると, 分画別抽出法は densitometry に比べて albumin が約 $8 \%$ 高く, r-globulin は約 $5 \%$ 低い值を得た。しかし，ネフローゼ血清，肝硬 変血清ではこの傾向がみとめられず，時に逆の結果の得 られることもめつた。

3） 18 才より 69 才に至る正常者 130 名の血清につい て, 分画別抽出法に上る血清蛋白分画值を求めると，そ の平均值を求めると, その平均值は albumin $62.8 \pm 1.2$ $\%, \alpha_{1}$-globulin $5.6 \pm 0.6 \%, \alpha_{2}$-globulin $6.9 \pm 0.7 \%$, $\beta$-globulin $9.0 \pm 0.8 \%, r$-globulin $15.7 \pm 0.5 \%$ であ り，各年代別にとくに有意な差がみとめられず，また 20才代に拉ける男女間の比較では, やはり有意の差はみ とめなかつた。

\section{文献}

1). 阿部正和他：生物物理化学 4,62,(1958)

2）橋敏也：濾紙電気泳動シンポジウム第 1 集, 文光 堂, 109, (昭 33)

3）綗敏也他: 生物物理化学 5, 77, (1958)

4）杉本良一他：生物物理化学 5, 99, (1958)

5）㼲敏世他：生物物理化学 6,63,(1959) 